\title{
Decision-making Process in the Systemic Strategy for Environmental Protection
}

\section{Proces decyzyjny w systemowej strategii ochrony środowiska}

\author{
Grzegorz Embros
}

\author{
Cardinal Stefan Wyszyński University in Warsaw \\ Faculty of Christian Philosophy \\ ul. Wóycickiego 1/3 budynek nr 23 01-938 Warsaw, Poland \\ E-mail: g.embros@uksw.edu.pl,ORCID:0000-0003-0861-6291
}

\begin{abstract}
The article attempts to demonstrate the role of decision-making process in actions for sustainable development implemented as part of environmental protection, which is viewed here in a systemic way. The article presents the definition of a system and its surroundings (environment), and points out that environmental protection can be described in this systemic perspective both in general and specific terms. This makes it possible to indicate the scheme and structure of decision-making process. The article examines the possibility of applying Mazur's control system for designing a scheme of actions that would be adequate for environmental protection, with emphasis placed on the optimisation stage. The author shows that the system developed by Mazur can be used in the PDCA methodology, which is based on the Deming cycle and included in the ISO 14001 standard. As a result, the potential of the systemic approach to environmental protection is shown and it is explained how to move from this approach to a broader strategy for environmental protection and ultimately, to the implementation of sustainable development goals.
\end{abstract}

Key words: sustainable development, environmental protection, environmental management system, decisionmaking process in environmental protection, optimisation

\section{Streszczenie}

$\mathrm{W}$ artykule podjęto próbę wskazania roli procesu decyzyjnego w działaniach podejmowanych na rzecz zrównoważonego rozwoju realizowanych w ramach ochrony środowiska ujmowanej systemowo. Przedstawiony został charakterystyczny dla tego ujęcia sposób określania systemu i jego otoczenia (środowiska) wraz ze wskazaniem możliwości opisu ogólnego oraz szczegółowego ochrony środowiska w tej perspektywie. Dzięki temu, możliwe było wskazanie schematu i struktury procesu decyzyjnego. Analizie poddano możliwość wykorzystania systemu sterującego Mazura, w konstruowaniu schematu postępowania, adekwatnego dla ochrony środowiska, ze szczególnym uwzględnieniem etapu optymalizacji. Autor wskazał na możliwość wykorzystania tego systemu w metodyce PDCA opartej na cyklu Deminga i uwzględnionej w normie ISO 14001. W efekcie możliwe było wskazanie potencjału systemowego ujęcia ochrony środowiska oraz ukazanie ścieżki przejścia od takiego ujęcia do konstrukcji szerszej strategii ochrony środowiska a w konsekwencji do realizacji celów zrównoważonego rozwoju.

Słowa kluczowe: zrównoważony rozwój, ochrona środowiska, system zarządzania środowiskowego, proces decyzyjny w ochronie środowiska, optymalizacja 


\section{Introduction}

Implementing the agenda for sustainable development is a task for today and a challenge for the future. The implementation of this agenda is based on actions carried out as part of broadly understood environmental protection. All human actions in this area include decision-making. In fact, the effectiveness and adequacy of actions to protect the environment depend on decisions made by people. It can be stated that actions for environmental protection, viewed as an element of sustainable development, are in fact embedded in the decision-making process. The specific nature of issues considered here allows for adopting a systemic perspective. Sustainable development can be viewed as a system with a specific structure and consisting of elements that interact with each other. One of these elements is environmental protection. It is a special case of the (sub) system by means of which man manages sustainable development. The systemic approach to the decisionmaking process, with man as a decision-maker, will be compatible with the proposed approach. In this way, the decision-making process, along with the act of making a decision, is assigned to the system of sustainable development.

The article attempts to present the components of decision-making process in the area of environmental protection, as well as to determine what this process is conditioned on and what stages it includes. Considering the impact that decision-making has on areas that are essential for the well-being of man and nature, it is important that this process should be properly designed and carried out. One can put forward the hypothesis that decision-making is inept, ineffective, inappropriate and flawed if it ignores the context in which decisions are made, if it fails to apply the principles for efficient and effective actions (praxeology), and if it does not refer to some specific set of values (axiology). Ineffective decision-making in the area of environmental protection makes it impossible to achieve positive results in relation to the three capitals of sustainable development: natural, social, and economic. As a result, it does not help to overcome the ecological crisis, but on the contrary, it may lead to aggravating this crisis and may pose a threat to achieving sustainable development goals (A).

\section{Environmental protection in the systemic ap- proach}

The reflection on environmental protection should start with a proper and precise definition of what is commonly referred to as environmental protection. It is important to determine how the term 'environment' is understood in this context, as well as what environmental protection consists in and should consist in.
In the literature on the subject, one may find a variety of definitions of environmental protection, depending on what aspects are focused on. These may be legal aspects (Boć, Samborska-Boć, Nowacki, 2008, p. 45), issues related to environmental management (Poskrobko, 2007, p. 47-49; PN-EN ISO 14001, 2005 and 2015), or natural aspects (Dobrzański, 2009, p. 19-40; Lonc E., Kantowicz, 2005, p. 17-22). It should be noted here that although environmental protection is founded on natural sciences, and overcoming negative impacts on nature is entrusted to technology, it does not seem justified to reduce all actions for environmental protection only to nature protection or environmental engineering. The issue of environmental protection increasingly often includes social aspects (education, law, management, economics, politics, etc.) that focus on the role of man in this area. This can be seen in emphasising social aspects in the context of the idea of sustainable development, which are then frequently referred to in various international and state documents.

Actions for environmental protection are particularly important in the case of large enterprises, which make use of and affect different environmental components. This includes both the exploitation of natural resources and emission of harmful substances, as well as exerting a considerable impact on the social environment in which a company operates (Des Jardins, 1998, p. 825-838). This perspective stresses legal aspects of environmental protection as well as various problems related to environmental management, or environmental resource management - as it is referred to in the specialist nomenclature. Decisions and actions carried out as part of environmental management concern environmental issues, focusing on water, air or soil pollution. The latest advanced environmental engineering solutions are frequently used; however, increasingly often, the context or social environment is also taken into account (Argandona, 2004, p. 41-52).

The systemic view favours an integral approach to environmental protection in environmental resource management, taking into account natural, technical, legal or economic issues, as well as broadly understood social issues (cultural component of the environment). The latter find a special place in the new version of the international ISO 14001: 2015 standard, which serves as a basis for developing environmental management systems (EMS). This shows the inter- and multi-disciplinary nature of environmental protection, which presents decision-makers with many challenges and problems, both theoretical and above all practical ones. It is necessary to identify problem areas and specific problems, and to bridge the gap between the theory and practice (Walker, 2006). 


\section{Man and the environment}

The interdisciplinary, diverse and complex nature of the issues discussed requires identifying a right perspective for sustainable development (Pawłowski, 2008) and for its key element, i.e. environmental protection, in particular. The systemic approach seems to be adequate both to the specific nature of environmental protection and to the tasks and problems identified in this area (also the ones determined in reference to sustainable development). Although the term systemic tends to be overused now, the systemic approach is not as common as it may seem. That is why, it is worth re-examining it and applying it in a proper manner.

The systemic approach emphasises a system and its environment. The environment of a system is defined as everything that is outside this system and that may affect it (external input of the system) or that is affected by the system (external output of the system) (Kempisty, 1973, p. 291). The system interacts with its environment and affects it, leading to its transformation. The environment is viewed in a multi-dimensional way as something that is outside the system and is actively transformed by it (Hull, 2006, p. 107-108). Broadly speaking, the environment includes both natural and cultural components (science, technology, art, and religion) (Dołęga, 2002 , p. 7-8). In the remainder of the article, the environment will be understood in this broad view - as everything that is outside the system and is transformed by it.

The adopted systemic perspective impels us to make an attempt at determining what system functioning in a given environment can transform it in a way that constitutes a threat to this environment (leads to its destruction, or degradation). In other words, what system makes environmental protection necessary? We consider a special case of the system that by making use of environmental resources, initiates processes leading to the regeneration of the environment. It is also able to notice (reflect, and not only react) that the system has previously disturbed functioning of the environment or its components. The systemic approach enables us to identify this special case of a system which affects its environment to such an extent and in such a scale ${ }^{1}$ that it may damage its structure, disrupt properties and functions (of the environment and / or other systems in the vicinity); or, in extreme cases, it may completely destroy them (i.e. deprive them of their ability to reproduce the structure, and restore the properties and functions of the systems involved).

This perspective makes it necessary to determine the parameters for the proper functioning of systems in

\footnotetext{
${ }^{1}$ The term scale is used when referring to ecological crisis, which - as some claim [e.g. Zbigniew Hull] has a global (scale of the whole globe) and total character (it can be seen in all spheres of human activity). This is debatable
}

the biosphere. In the systemic approach, one can refer to the state of a system that is called functional equilibrium. It was described, among others, by Marian Mazur, who defined it as the state in which physical quantities in an autonomous system take the most optimal values, i.e. values most distant from those that are too low and too high from the point of view of the system's ability to control itself, i.e. from those that may cause destruction of the system (Mazur, 1966, p. 57). This definition mentions critical parameters; when these are exceeded, the system's structure is destroyed, or the system is unable to regain its properties or functions (e.g. the ability to control itself, ability to prevent loss of control or adaptation, etc.). The question arises whether there are some methods and tools that can be used to determine these critical parameters. Here we can see an undeniable advantage of the systemic approach to environmental protection; i.e. identifying main (real) tasks and challenges in the field of environmental protection that face the natural sciences, ecology, environmental engineering, etc.

These problems were examined by Urlich Beck, among others. In his book Risk Society7, he critically assessed the idea of setting acceptable levels for toxic substances. He wrote: Those who nonetheless set acceptable levels for individual toxic substances, either proceed from the completely erroneous assumption that people ingest only a particular toxin, or from the very starting point of their thought they completely miss the opportunity to speak of acceptable values for people. The more pollutants are put into circulation, the more acceptable levels related to individual substances are set, the more liberally this occurs, and the more insane the entire hocuspocus becomes, because the overall toxic threat to the population grows -- presuming the simple equation that the total volume of various toxic substances means a higher degree of overall toxicity (Beck, 2002 , p. 86). He also points out that the situation is similar for the synergism of individual toxic substances; especially when scientists have a problem with determining the effects of the synergy of these multiple toxins. Thus, it may turn out that the effects of particular toxic substances in reaction with others permitted through acceptable levels may be harmful although partial toxic effects are not.

In his book Green Philosophy, Roger Scruton points out that environmental problems arise largely because human purposes, pursued in a linear way, destroy homeostatic systems (Scruton, 2017, p. 40). He shows the connection between the issues related to the equilibrium and stability of systems and those connected with the risk of exceeding the limits for proper functioning of these systems. Scruton writes

(e.g., there is no consensus as to the global character of ecological crisis). Instead of the term scale that may have various connotations, one can use the term range of influence. 
explicitly: Environmental problems involve managing risk. This means assessing what can and cannot be changed, the likelihood of adverse and beneficial consequences, and the agencies best suited to manage risk on our behalf (Scruton, 2017, p. 124). In this way, in the systemic approach, the issue of functional equilibrium or acceptable limits connects human actions in relation to the environment with risk analysis (Kiepas, 1999, p. 57-70).

Despite the difficulties mentioned above, attempts are made to determine the scale, degree or extent of acceptable and not acceptable impacts (interferences). These are referred to as acceptable or unacceptable risk levels. This also concerns conservation activities and is connected with the question of how much humans may interfere with the environment not only when it comes to exploiting its resources, but also when undertaking actions to protect some species of plants or animals (Latawiec, 2016, p. 7797). Exceeding acceptable levels of interference with the nature in order to protect some species or some area may also disrupt the structure, functions or properties of this species or area.

From the perspective of environmental protection viewed in a systemic way, it is justified to highlight man (society) in relation to the environment he transforms. It seems that the necessity of protecting the environment cannot be justified on account of any other system but that of man. At the same time, the feedback between the system and its environment, which is emphasised in the systemic approach, enables us to see also the impact of this environment on the system that functions in it. The environment degraded by man exerts a degrading effect on man as well (e.g. diseases of affluence).

Man, through his actions, can be a threat to the environment in which he lives, but his impact on the environment may cause that he himself will become subject to increasing threats from the devastated environment. In this way, man brings about an ecological crisis (Hull, 1998, p. 23-31; Hull, 1990, p. 9399). This ecological crisis can be described as the critical situation when man is forced to take specific decisions and actions. In other words, this is a situation when we can see the effects of exceeding limits, which results in disturbing the functional equilibrium of certain systems, and increasing the risk level. It is only man that is capable of understanding the seriousness of this problem, and not just reflect on it, but also react by taking right decisions and intensifying actions aimed at reducing or eliminating threats. Thus, analyses concerning the decision-making process become the central point of environmental protection, which also determines the place of man in this area.

Only man can consciously destroy the environment, but also he can protect and care about it. It seems that the above analyses justify the statement that in the systemic approach we are dealing with the protection of man in his environment or the protection of the environment for the sake of man who functions in it. This should not be confused with protecting the environment from man, which does not follow from the systemic approach to environmental protection. The systemic approach emphasises mutual relations and feedbacks between the system and its environment, and therefore protecting the environment from the system which functions in this environment would lead to disrupting or breaking these relations, feedbacks, or interactions - i.e., to some isolation of the environment from the system and/or the system from the environment. This could result in the emergence of a closed (isolated) system or systems, and would have negative consequences for this system(s). Possibly, this could also have adverse effects on the environment (as the super-system of various closed subsystems, i.e. subsystems that do not interact with the environment). Finally, the environment from which man has been isolated ceases to be the environment of man. Hence, talking about environmental protection would become senseless.

U. Beck writes that it is threats that flush man out of the environment (Beck, 2002, p. 95-96). This means that the degradation and destruction of environment lead to the isolation of man and of the environment (especially of its natural component). Zbigniew Hull states that disrupting the relationship between man and the nature causes an ecological crisis. He points out to the barriers that block mutual relations in this system, making it impossible to overcome the crisis. Therefore, environmental protection understood as the protection of the environment from humans seems to be not only unjustified from a systemic point of view, but also incompatible with the goals of environmental protection. This, of course, does not exclude specific situations in which the scale, degree or extent of human interference into certain components of the environment legitimise introducing certain restrictions (measures for nature protection - strict nature reserves, etc.).

In the remainder of the article, man will be considered as a special case of the system in the environment (surroundings) that he transforms to create his own environment. The environmental protection system is a product developed by man. At this point, it is necessary to specify the goals of this environmental protection system constructed by man. Of key importance seems to be the way of carrying out actions for environmental protection (viewed in a systemic way) in order to develop a systemic strategy for environmental protection.

\section{Environmental Protection}

The environment sets specific tasks for the system (Laszlo, 1978, p. 70; Dubos, 1986, p. 69). To handle these tasks, the system is forced to increase efforts and intensify actions, which usually means increasing demand for energy necessary to power it. This in turn makes it necessary to use environmental re- 
sources. Remedial actions of the degraded environment, especially when they are aimed at global phenomena (Scruton, 2017, p. 63-64) are a special case in point. In other words - the larger the scale and extent of threats to the environment, the more resources and energy (drawn from this environment) are needed to protect it. This paradox of environmental protection shows methodological difficulties that influence decision-making on the one hand, and specific guidelines for decision-making in relation to environmental protection, on the other hand. It is necessary to find such forms of the broadly understood decision-making process that will be as much energy-efficient as possible and will not contribute to increasing the demand for resources (Alexander, 2007, p. 155-162).

In view of the above, Robert Wiener's statement that informational activity is the least energy-consuming (Wiener, 1961, p. 42), can be treated as an inspiration to focus more on the systemic informational perspective (Bateson, 1996, p. 147-148). Actions in this area, such as organisation, management, education, activities in the info-sphere etc. will remain energy efficient and economical (requiring relatively little resources), even if they are intensified. Thus, they meet an important criterion for actions carried out as part of environmental protection.

The system consumes energy also in order to preserve its structure, properties and functions, and to counteract entropy (Zięba, 2013, p. 94-131; Mynarski, 1979, p. 52-63, 97, 118-119). By specifying the system's properties (homeostasis, stability, adaptation, and couplings) and its functions (control, connectivity, transport, or information), the systemic approach puts into focus the problem area designated for actions that are undertaken for environmental protection. As Roger Scruton notes, I see the environmental problem as arising from the loss of equilibrium that ensues when people cease to understand their surroundings as a home (Scruton, 2017, p. 40). This shifts the perspective of viewing key areas of environmental protection, moving away from selected components of the environment (these are most often: water, air, and soil), to focus on the structure, properties and functions of systems. The focus is then on the mechanisms and ways of organising systems or processes that are taking place. In this way, positive environmental changes concerning water, air, or soil become somehow an effect or result of environmental protection viewed in the systemic way, where the process, organisational and structural references, etc. are given a proper place. In this perspective, components of the environment constitute a kind of scenery of the scenario of actions (cf. concrete system of actions in Michel Crozier's view: Crozier, 1982, p. 221-283). They are part of the context that we must monitor and identify the mechanisms of their mutual relations and interactions. In this way, input data for the decision-making process are obtained (ISO 14001: 2015, item 4).
Today, actions for environmental protection are based both on science and technology, as well as on the postulates of sustainable development, environmental management systems and environmental law. It seems reasonable to seek the essence of environmental protection in these areas. For reasons of space, it is impossible to examine all of them in this article and so a choice must be made. All actions that have a considerable impact on the environment are subject to environmental law. This is why we will first refer to the definition of environmental protection in the Environmental Protection Law. Environmental protection is defined there as: the taking of action or the abandoning of activities to allow the preservation or restoration of a natural equilibrium; in particular, such protection consists of: rational development of the environment and management of natural resources in accordance with the principle of sustainable development; prevention of pollution and restoration of natural elements to their proper status (B).

This definition of environmental protection may raise some doubts and lead to ambiguities. First and foremost, it is not clear how terms such as natural equilibrium, rational development, rational management, or restoration of natural elements to their proper status should be understood (e.g., what state in this case can be described as rational or proper?). Moreover, one may ask whether this definition really describes environmental protection, as it seems to reduce the whole problem only to nature conservation. This entails the risk of lack of consistency when formulating specific provisions of environmental law based de facto on the definition that emphasises only the natural elements of the environment (limited problem area).

Without going into further analysis, it should be pointed out that referring to such an awkward definition of environmental protection as the one in the Environmental Protection Law, seems to be at the very least risky. Instead, it will be more beneficial to employ the systemic approach here. It enables us to formulate the definition of environment and may refer to action or lack of action (failure to act) - taking into account mutual relations between the system and its surroundings. This approach offers a simple (simplicity of synthetic approaches) and appropriate platform for describing what environmental protection is.

The systemic approach enables us to specify the purpose of protection, which is to preserve the structure, properties and functions of the systems involved; to shape proper relations between those systems and their elements; to preserve proper organisation; to maintain the systems' ability to self-regulate and to maintain functional equilibrium, or to counteract the loss of self-control. These general aims determine the scope of actions for environmental protection and help to establish what this protection should involve. This also makes environmental protection ac- 
tions more effective, which in turn enhances the chances of achieving sustainable development goals. The analyses carried out so far have made it possible to formulate the definition of environment, identify the system functioning in it, and describe its properties and functions. This translates into defining the general goal of environmental protection in the systemic approach. This goal is connected with the need to take specific decisions followed by actions. Consequently, the issue of environmental protection is expanded to include the decision-making process in its broad interpretation, which reveals a practical dimension of environmental protection.

It is worth mentioning that the perspective presented above fits in with what experts often formulate as the aim of environmental protection, which is to ensure that man can live, survive and develop (Lonc, Kantowicz, 2005, p. 17-22). Inspired by Konrad Lorenz, Zbigniew Łepko adds that: it is not only about surviving somehow, but about surviving in a humane way (Łepko, 2013, p. 24; Łepko, 1998, p. 61). It is noteworthy that the category of development included in the aim of environmental protection, adds axiological issues to our considerations, when development is understood as a process of changes assessed positively from the point of view of some specified criterion; the basic criterion for assessing whether something is positive or not is the value system (which is an axiological criterion) (Borys, 2013, p. 560). Thus, the issue of environmental protection is broadened to include topics that are not directly related to natural or engineering sciences. We can easily see here the idea of sustainable development and so it would be groundless to refer only to natural and engineering sciences. It is necessary to seek a more adequate approach. It seems that the systemic approach has the potential to capture this wide range of problems. This approach, employed in the fullest possible form and in many dimensions can form the basis for developing a (comprehensive) systemic strategy for environmental protection and then specific action schemes (the appropriate methodology).

\section{Decision-making}

Decision-making entails identifying problems, classifying them and explaining their nature or causes in terms of both what conditions them and how they can be solved. The solutions obtained in this way constitute the process of indicating the action objectives. This is a starting point for developing possibly the most complete list of measures necessary to achieve the desired goals and for identifying the side effects of each of these measures. Once this is done, a decision may be taken, and we can move on to the implementation stage.

Having identified the goals and tasks that determine actions for environmental protection, we need a pattern of conduct that would be suitable for implementing these goals (Kossecki, 2005, p. 35-37). The con- cept of control system put forward by Marian Mazur is worth our attention here. One should also mention the so-called Deming cycle and in particular, the PDCA model (Blikle, 2015, p. 37-46; PN-EN ISO 14001: 2015, p. 6), which plays an important role in environmental management. In further considerations, the decision-making process will not be viewed only as an individual decision act, but it will be examined in a broad sense, as the one represented by Mazur's control system and taking into account the PDCA model.

The main purpose of diagnosing the decision-making process in relation to environmental protection is to identify and indicate its constitutive features, components and properties, and to reveal its malfunctions (in particular, those factors that reduce its effectiveness), to identify the source of those malfunctions, and to determine their influence on the three pillars of sustainable development: social, natural and economic.

What is important for decision-making is the context in which it takes place. It is possible to identify problems that may significantly hinder making decisions concerning environmental protection. First and foremost, these are problems arising from the conceptual and methodological chaos in the area of environmental protection. The definition of environmental protection in the Environmental Protection Law is a good case in point here. This definition ignores or marginalises the importance of systemic approaches and of information as an essential component of reality. Decision-makers not only run the risk of having not enough information, but they also tend to avoid many important problem issues in this area. Also they are not willing to take responsibility for man and the environment. On the other hand, in some critical or emergency situation, different justifications are offered or attempts are made to transfer the consequences of such situation onto society or other components of the environment (Kosewski, 2008, p. 13-66; Beck, 2002, p. 32-33, 36; Scruton, 2017, p. 178-179; Klein, 2016, p. 74-173). All this may be the reason behind problems connected with the proper establishment of goals (Kay, 2010, p. 2122) or adequate tools, models, methods for identifying and solving those problems (threats). At the stage of planning, optimisation is omitted, or alternatively some forms of planning or maximisation (in technical terms) are carried out. Often, only the economic capital is taken into account, while natural and social capitals are ignored. The importance of a properly structured decision-making process is underestimated in formalised environmental management systems. Also, the problem of environmental protection is reduced to environmental engineering, nature protection or ecology, and the issues concerning environmental protection are assigned exclusively to the natural sciences. Such a perspective may lead to eliminating anthropological issues from the area of environmental protection, or possibly to 
viewing humans only as consumers of resources or emitters of harmful substances. This may easily lead to treating man only as the one that exerts either positive or negative influence on the environment, and as such must be the subject to environmental law. In this perspective, a full picture of the environment and man in the environment - also as the one that causes some action, gets blurred or completely lost. In this case, praxeology, axiology or ethics often become of secondary importance or are completely excluded from the issues concerning the environmental protection. This results in difficulties in describing man and his place in the world. Such distorted picture of the world or man can create further difficulties. For example, it can be problematic to determine man's relation to his surroundings and then the nature of man's interactions with the environment. As a result, the decision-making process may isolate the system of man from the environment and vice versa, as has already been mentioned.

This explains problems in carrying out environmental protection actions in accordance with sustainable development and the EU and state directives. On the other hand, at the level of organisations, it is difficult to adjust actions carried out for environmental protection to meet the ISO 14001 standards (especially after these were amended in 2015). It is not clear why actions for environmental protection (so much reduced) should include, for example, the principles of corporate social responsibility (Line et al., 2007). It can be stated that the indicated difficulties have an adverse effect on both actions related to interfering with the natural components of the environment, compliance with the environmental law, and economic effects.

The scope of this article allows only for a rather cursory enumeration of problems that appear in the context of decision-making preceding actions for environmental protection. This issue certainly deserves a more in-depth study. However, it should be emphasised that it is important to identify and classify some problem areas in this context as well as certain specific issues that precede the decision-making process. Knowing them and being aware of how important they are in decision-making can translate into developing specific scheme of actions, which could result in making decisions adequate to the postulated goals, and consequently would lead to taking efficient and effective actions. Ignorance in this area, and not being aware of the importance of the context in which decision-making takes place, or of what determines it, may result in some failures in this process, which means taking inept, inefficient, or ineffective actions. In the case of interfering with the environment, this may bring about negative consequences in relation to the three capitals of sustainable development. Such actions, although designed to protect the environment, may in extreme cases turn out to be harmful to the environment understood in a broad way.

\section{Marian Mazur's control system}

The phenomena and difficulties mentioned above do not facilitate decision-making. Thus, it is even more important to indicate an adequate course of action that would minimise their negative impact on decision-making. Due to its substantive merits, which will be discussed in more detail further on, the concept put forward by Marian Mazur has been chosen here. Mazur defines a control system as the one that is at the same time a postulator, optimiser and implementer. In the control process, it is necessary to specify the changes to be made in the system (postulation) and methods (optimisation) to bring about these changes (implementation). These three elements are coupled with each other and with the environment. The first element is the optimiser, which is responsible for optimisation processes. It is coupled with the environment, which makes it possible to observe the environment and how it is changed. It is also coupled with the postulator - the second element of the system, which is responsible for indicating the goals to be achieved. Thanks to this coupling, it is possible to determine interdependencies between methods and goals. The postulator is coupled with the implementer, which is responsible for implementing the goals indicated by the postulator. As a result, it is possible to determine the correlation between methods and goals. The implementer is coupled with the environment, thanks to which it is possible to determine the means of modifying the environment and power supply (Mazur, 1976, p. 102-103). The final stage of decision-making involves implementing the goal indicated at the stage of postulation by means of a decision that has been optimised, and making use of the means determined by the implementer. Mazur notes that in a control system it is noteworthy that optimisation and implementation are coordinate processes in relation to postulation. This means that methods and means are dependent on goals, and goals are dependent on methods and means, but also that, through postulation, methods are dependent on means and means on methods (Mazur, 1976, p. 113). The control system described above takes into account the main task of optimisation. This task is to determine all the courses of action that can lead to achieving the goal specified in the postulation, to identify side effects of each of them and to indicate the optimal decision, or in other words, a course of action that leads to the goal and produces the most beneficial side effects (Mazur, 1976, p. 102-103). Choosing the optimal decision is entangled in specific problems of decision-making. These problems were pointed out by Klemens Szaniawski, among others (Szaniawski, 1994, p. 286-304, 402-410, 431444).

It seems that such structure of the scheme for decision-making, enables us to include, justify and indicate the place in the decision-making process for all those issues that were often ignored, or the inclusion 
of which was difficult to justify, or attempts were made to impose them arbitrarily. These are, for example, praxeological assessments (guidelines for efficient action), or axiological issues (Embros, 2016, p. 101-127). In the scheme proposed above, they will be placed at the stage of planning, or more precisely - at the stage of optimisation (Gasparski, 2004, p. 51-56). Taking into account praxeological or axiological determinants of decision-making may significantly enhance the process of optimisation, and thus increase the chances of arriving at the optimal decision. Taking the optimal decision results in actions that produce the most beneficial side effects (which is the main criterion for optimisation). Thus, the risk at this stage is minimised. The means that lead to achieving a specific goal are indicated, taking into account the widest possible range of context factors (according to ISO 14001: 2015, item 4; cf. also Crosier, 1982, p. 124-125).

The advantage of the presented scheme is that it puts an emphasis on the optimisation stage. It encourages us to use specified terminology and methodology in the entire decision-making process. Moreover, it allows for including many important elements that should be taken into account. Consequently, we are more likely to avoid actions that bring about side effects adverse to many elements of the controlled structure. However, as much as this scheme allows for some simplification and ordering of issues, we are still left with a very complicated set of many systems that are dynamically interconnected. This gives rise to many difficulties that result from both a holistic approach to such complex and complicated issues, as well as from specific problems related, for example, to the proper identification of goals, planning, projecting (programming) or making decisions in the optimisation process, determining side effects of decisions and actions (projecting) (Beck, 2002, p. 34-36).

Therefore, it is imperative to use some tools that would support the described control process. These include systemic instruments by means of which it is possible to keep the terminology in order and to organise complex problems in the ordered structure of elements, identifying and defining the relationships between these elements. It seems reasonable to refer here to praxeology, decision theory, management theory, or game theory (e.g., the one put forward by Crozier, 1982, p. 110-122). The important role of optimisation and information processing in control (management) results in the increased importance of knowledge drawing on the latest scientific, technical and technological achievements - particularly information systems (Michnowski, 2003, p. 107-119; Michnowski, 1999, p. 57-65). This shows that the decision-making process is entangled in extensive problem areas, which further complicates the whole issue. This makes us aware of the challenges and tasks that specialists in environmental protection have to face (Van Der Vorst, 1998, p. 171-179). It seems that priority should be given to simplifying the decision-making process by means of available tools. It is sometimes postulated that we should move away from specialisation as it is understood now to specialisation in the holistic approach (Beck, 2002, p. 90, 273-274; Saint Marc, 1979, p. 191-192). Risk analysis is successfully used in environmental management to determine whether the risk level is acceptable or unacceptable. Such analysis provides some reference point and support when making decisions on actions that may have a specific impact on the environment (Goodwin, Wright, 2008). Another tool is the SWOT analysis and the risk and opportunity analysis, which determines the negative and positive effects for particular factors of the context in which an organisation operates and important aspects, as well as takes into account the product life cycle - which is included in the new ISO 14001: 2015 standard.

\section{Environmental management system}

The analysis carried out provides a new interesting perspective on environmental protection. As mentioned before, the aim of actions for environmental protection is to enable people to live and develop. According to Franciszek Piontek, the category of $d e$ velopment includes three types of capital: human, economic and natural, and emphasises man's subjectivity and creativity (Piontek, 2007, p. 57-58). If man is to be treated as a control system as understood by Mazur, then there are three controlled systems, i.e. social, economic and natural. The term control may be replaced here with the term management, which is more common in everyday practice. Therefore, the described mechanisms can concern development management, taking into account all of these elements (society, economy, and nature) as equally valuable. Man who functions in the environment (natural and cultural) and is interrelated with it, is an active subject in management. It is for the sake of man that attempts are made to overcome ecological or economic crises. It is irresponsible human activity that causes these crises. It is poor or incompetent management that may lead to disruptions in the relationship between man and the environment (these disruptions, according to Hull, are the cause of the ecological crisis).

Environmental management plays an important role in environmental protection. The procedure that is recommended in ISO 14001 and that forms the basis for developing formalised environmental management systems, is the Deming cycle. This methodology describes the steps in decision-making process, which in turn affects the implementation of specific actions for environmental protection. Hence, the appropriate scheme is extremely important from the point of view of achieving environmental objectives. Any deficiencies or flaws in this scheme may make the entire decision-making process deficient and 
flawed, and result in actions that adversely affect the environment and man who functions in it.

The international ISO 14001 standard is based on the methodology Plan, Do, Check, Act (PDCA) (PN-EN ISO 14001: 2015, item 7(0.4)). It does not include the stage of optimisation, which seems to be a significant deficiency. The stage of planning is followed directly by implementation and it is not clear whether optimisation procedures are automatically included in planning or not. It should be emphasised here that when we deal with such a complicated issue as environmental protection that translates into practical actions and if a plan turns out to be ill-conceived, then the effects of actions resulting from such a plan may be adverse, as well. It seems that disregarding the optimisation stage in such an important and commonly used model may have serious consequences both for the natural environment and man. In such cases, limiting or eliminating important components of the model or assuming that they will appear naturally at the stage of planning or implementation, cannot be justified (Pszczołowski, 1984, p. 318-325).

The decision-making concerning environmental protection could take place in line with Mazur's control system, with particular emphasis given to the optimisation stage (as it is understood by Mazur). It seems that it would be possible to add this element to the PDCA cycle, which after all reiterates the importance of checking and continuous improvement. Then, the environmental management system could be based on more specific methodological foundations, and the decision-making process would consist of the following stages: solving cognitive problems (identification, classification, explication) (Mazur, 1976, p. 99-101); solving decision problems, in particular: postulating; i.e. indicating goals; planning that consists of optimisation and scheduling the actions; and doing/ implementing. It should be emphasised that by including optimisation in the model, we equip the decision-making process with analytical tools that are not available at the planning stage. Moreover, optimisation enables us to learn and apply knowledge and experience. If learning occurs before the stage of implementation and doing, it may reduce the risk of learning from mistakes, and so minimise the risk of financial, environmental, or social costs. The stages that follow planning and are related to checking and reviewing the system with a view of continuous improvement, should also include optimisation. If any deficiencies in doing are revealed during the check phase, it should be possible to return to the optimisation stage (not to postulation, because the goals remain the same, while the means of achieving them are altered, taking into account the conclusions resulting from the experience gained). Thus, learning resulting from the check stage is included in the decision-making process.
In the methodology structured in such a way, the plan stage would focus on scheduling actions that would lead to accomplishing postulated goals. Optimisation (including: modelling, simulation, risk and opportunity analysis, etc.) would constitute a key moment in the broadly understood decision-making process. Taking the optimal decision (i.e. decision that meets the main optimisation criterion) would be followed by a transition to doing/ implementing. Finally, it must be emphasised once again that many issues that could not be properly addressed in the plan phase could be taken into consideration in the optimisation phase.

The extended methodology proposed here enables us to take into account the conditions and context in which decision-making concerning environmental protection takes place. With continuous improvement of the environmental management system in view, the check stage may include not only the assessment of documentation quality, and of environmental, legal or economic issues, but also, for example, praxeological, axiological or ethical assessment. The latter one can be done by referring to ethical management models, for instance ethics auditing, which is currently in use (Gasparski, 2013, p. 460473; Garcia-Marza, 2005, p. 209-219).

The problem of making a decision (i.e. selecting the most effective or efficient action) that occurs at the optimisation stage reveals not only praxeological guidelines for efficient action, but also emphasises the act of choice. Hence, it is necessary to specify in relation to what this choice will be made. The definition of optimisation perspective adopted in the article is in line with the common understanding of this term; i.e., as the principle of rational resource management or economically efficient action. This is a prerequisite for building organisational efficiency, though it is not sufficient (Gasparski, 2013, p. 460473; Gasparski, 2004, p. 49-77). The presented approach to decision-making with a particular emphasis given to optimisation (as seen by Mazur) enables us to include those issues that could not find their proper place in the traditional approach. This is in line with the statement that it is not possible to speak of the optimisation of economic processes when this is not accompanied by axiological, ethical, and cultural reflection (Krupa, 2005, p. 344). As Gasparski writes: A professional is a person who adheres to the standards of the profession (...). These standards constitute for themselves the axiological context of the ' 3 E's': praxeological effectiveness (efficiency), economy, and ethical values (Gasparski, 2004, p. 174-175). The decision-making process founded on axiology may take a wrong course because decisionmakers are not aware of this fact, and so in their decision-making they tend to overlook issues related to specific values or specific (moral) standards of conduct. 


\section{Conclusion}

The article attempts to define the systemic strategy for environmental protection based on the systemic approach. Both the environment and its protection are viewed in systemic terms. The article gives the definition of a system and its environment in the systemic approach and points out that environmental protection can be described in this systemic perspective both in general and specific terms (including the goals). The systemic approach emphasises impacts connected with the system transforming its environment and the feedback of the transformed environment on the system, which then reacts (responds) to these interactions. This allows for pointing out the special case of a system in the environment, i.e. man in his surroundings (environment).

When considering human impact on the environment, it turns out that the issue of our interest is connected with the problem of action. While not every decision must lead to an action, each action is preceded by a decision. The article attempts to characterise the decision-making process in its broad meaning, placing a particular emphasis on decision-making in environmental protection. It identifies the main reasons that may make this process ineffective. An attempt is made to indicate the components of decision-making in the area of environmental protection and determine what conditions this process and how it proceeds.

Decision-making is more effective and efficient if we take into account the context in which it takes place and its conditions. The analyses carried out allow for indicating the context, structure and the most important conditions of decision-making (with particular emphasis placed on decision-making concerning environmental protection). The place and role of optimisation, as well as the importance of describing the process of decision-making (as precisely as it is possible) are pointed out. This perspective allows for specifying the scheme of decision-making. The adequate structure of this process, including its key stages, enables us to construct a specific scheme of actions.

The article examines the possibility of applying the control system put forward by Mazur, for designing a scheme of actions that would be adequate for environmental protection Moreover, it considers the PDCA methodology based on the Deming Cycle and used in Environmental Management Systems, that is included in the ISO 14001 Standard. The author points out the shortcomings of this methodology and suggests that it should be complemented by referring to Mazur's control system.

The analyses carried out do not only demonstrate the potential of the systemic approach to environmental protection, but also indicate how to move from this approach to a broader strategy for environmental protection. This strategy can be founded on the proposed methodology and successfully applied as part of developing, maintaining and improving management systems, especially the environmental management system. It seems that this will lead to more effective actions for environmental protection, which may contribute to achieving the goals and tasks of sustainable development.

\section{References}

1. ALEXANDER J., 2007, Environmental Sustainability Versus Profit Maximization: Overcoming Systemic Constrains on Implementing Normatively Preferable Alternatives, in: Journal of Business Ethics, Kluwer Academic Publishers, 76, p. 155-162.

2. ARGANDONA A., 2004, On Ethical, Social and Environmental Management Systems, in: Journal of Business Ethics, Kluwer Academic Publishers, 51, p. 41-52.

3. BATESON G., 1996, Umyst i przyroda. Jedność konieczna, [Mind and Natur,e 1980] PIW, Warszawa.

4. BECK U., 2002, Spoteczeństwo ryzyka. $W$ drodze do innej nowoczesności, [Risikogesellschaft - Auf dem Weg in eine andere Moderne 1986] Wydaw. Naukowe SCHOLAR, Warszawa.

5. BLIKLE A., 2014, Doktryna jakości. Rzecz o skutecznym zarzadzaniu, Wyd. Helion, Gliwice.

6. BOĆ J., SAMBORSKA-BOĆ E., NOWACKI K., 2008, Ochrona Środowiska, Wyd. Kolonia Limited, Wrocław.

7. BORYS T., 2013, Hasło: rozwój, in: Biznes, etyka, odpowiedzialność. Podręcznik akademicki, ed. Gasparski W., Wyd. PWN, Warszawa, p. 560.

8. CROZIER M., FRIEDBERG E., 1982, Czlowiek $i$ system. Ograniczenia działania zespolowego, PWE, Warszawa.

9. CROZIER M., FRIEDBERG E., 1980, Actors and Systems. The Politics of Collective Action, University of Chicago Press, Chicago.

10. DESJARDINS J., 1998, Corporate Environmental Responsibility, in: Journal of Business Ethics, Kluwer Academic Publishers, 17, p. 825-838.

11. DOBRZAŃSKI G., 2009, Podstawowe pojęcia i problemy użytkowania i ochrony środowiska, in: Ochrona środowiska przyrodniczego, ed. Dobrzański G., Wyd. Naukowe PWN, Warszawa, p. 19-48.

12. DOŁĘGA J. M., 2002, U podstaw kultury ekologicznej, in: Podstawy kultury ekologicznej, ed. DOŁĘGA J. M., Wyd. Acta Uniwersitatis Masuriensis, Warszawa, p. 7-8.

13. DUBOS R., 1986, Pochwała różnorodności, [A God Within, 1972] PIW, Warszawa.

14. Environmental Protection Law of 27 April 2001, Article 3 (13), in: Journal of Laws dated 20 June 2001.

15. EMBROS G., 2016, Prakseologiczne uwarunkowania procesu decyzyjnego w ochronie środowiska, in: Studia Ecologiae et Bioethicae, 14/2016 (1), p. 101127

16. GARCIA-MARZA D., 2005, Trust and Dialogue: Theoretical Approaches to Ethics Auditing, in. Journal of Bussiness Ethics, 57, p. 209-219.

17. GASPARSKI W., 2004, Wyktady z etyki biznesu, Wyd. WSzPiZ im. Leona Koźmińskiego, Warszawa.

18. GASPARSKI W., 2013, Teorie oraz dylematy etyczne i prakseologiczne, in: Biznes, etyka, odpowiedzialność, ed. Gasparski W., PWN, Warszawa, p. 460-473. 
19. GOODWIN Ch., WRIGHT J., 2008, Environmental management plans, IEMA Best Practice Series, 12.

20. HULL Z., 1990, Świadomość kryzysu i kryzys świadomości, czyli człowiek wobec przyrody, in: Biuletyn Naukowy ART, Olsztyn, 93-99.

21. HULL Z., 1998, Istota i uwarunkowania obecnego kryzysu ekologicznego, in: Humanistyka Przyrodoznawstwo Technika w obliczu kryzysu biosfery. Materiały IV Olsztyńskiego Sympozjum Ekologicznego Olsztyn - Waplewo 10-12 września 1997, ed. Dębowski J., Olsztyn, p. 23-31.

22. HULL Z., 2006, Ekofilozofia i środowisko przyrodnicze, in: Diametros - Internetowy Serwis Filozoficzny, p. 105-115.

23. KAY J., 2010, Trudna sztuka decydowania, in: Dziennik gazeta prawna, nr 74(2705), Warszawa, p. 21-22.

24. KEMPISTY M., 1973, Hasło: Otoczenie, in: Maty stownik cybernetyczny, Wyd. WP, Warszawa, p. 291.

25. KIEPAS A., 1999, Etyka a ryzyko działań człowieka w środowisku, in: Ochrona środowiska $w$ filozofii $i$ teologii, ed. Dołęga J., Czartoszewski J. W., Wydaw. ATK, Warszawa, p. 57-70.

26. KLEIN N., 2014, This Changes Everything: Capitalism vs. the Climate, Simon \& Schuster, New York

27. KOSEWSKI M., 2008, Wartości, godność $i$ wtadza, Wyd. Vizja Press \& IT, Warszawa.

28. KOSSECKI J., 2005, Metacybernetyka, Kielce-Warszawa.

29. KRUPA M., 2005, 'Dżungla' teorii organizacji i zarządzania - poznanie zdeterminowane pytaniem o światopogląd ?, in: Annales. Etyka w życiu gospodarczym, Łódź, p. 339-349.

30. LASZLO E., 1978, Systemowy obraz świata, Wyd. PIW, Warszawa.

31. LASZLO E., 1972, The systems view of the world: the natural philosophy of the new developments in the sciences, George Braziller.

32. LATAWIEC M., 2016, Rozpoznawanie granic ingerencji człowieka w środowisko przyrodnicze, in: Studia Ecologiae et Bioethicae, 14(2016)1, p. 77-97.

33. LINE M., WOODHEAD J., CORT T., EULER A., 2007, Corporate Social Responsibility, IEMA Best Practice Series, Vol. 9.

34. LONC E., KANTOWICZ E., 2005, Ekologia $i$ ochrona środowiska, Wyd. PWSZ AS, Wałbrzych.

35. ŁEPKO Z., 1998, Spór o testament F. Bacona, in: Studia Philosophiae Christianae 34(1998)2, p. 5374.

36. ŁEPKO Z., 2013, Od etologii zwierząt do ekologii człowieka. in: Studia Ecologiae et Bioethicae, 11/2013 (3), p. 9-28.
37. MAZUR M., 1976, Cybernetyka i charakter, Wyd. PIW, Warszawa.

38. MAZUR M., 1966, Cybernetyczna teoria uktadów samodzielnych, PWN, Warszawa.

39. MICHNOWSKI L., 1999, Czy regres człowieczeństwa ?, Wyd. LTN-K, Warszawa.

40. MICHNOWSKI L., 2003, O potrzebie budowy informacyjnych podstaw trwałego rozwoju (sustainable development) polskiej, europejskiej i światowej społeczności, in: Filozoficzne i społeczne uwarunkowania zrównoważonego rozwoju, ed. Pawłowski A., Monografie Komitetu Inżynierii Środowiska Polskiej Akademii Nauk, vol. 16, Lublin, p. 107-119.

41. MYNARSKI S., 1979, Elementy teorii systemów i cybernetyki, PWN, Warszawa.

42. PAWŁOWSKI A., 2008, Rozwój zrównoważony idea, filozofia, praktyka, KIŚ PAN, Lublin.

43. PIONTEK F., 2007, Teoria rozwoju a personalistyczna koncepcja teorii ekonomicznej, in: Zarządzanie rozwojem. Aspekty społeczne, ekonomiczne i ekologiczne, ed. Piontek B., Piontek F., PWE, Warszawa, p. 55-62.

44. PN-EN ISO 14001, 2005 i 2015, Systemy Zarzadzania Środowiskowego - wymagania $i$ wytyczne stosowania, Warszawa.

45. POSKROBKO B., 2007, Zarządzanie środowiskiem, Wyd. PWE, Warszawa.

46. PSZCZOŁOWSKI T., 1984, Organizacja od dołu $i$ od góry, Wyd. Wiedza Powszechna, Warszawa.

47. SAINT MARC P., 1979, Przyroda dla czlowieka, PIW, Warszawa.

48. SCRUTON R., 2017, Zielona filozofia. Jak poważnie myśleć o naszej planecie [Green Philosophy: How To Think Seriously About The Planet 2012, Atlantic Books], Zysk i S-ka, Poznań.

49. SZANIAWSKI K., 1994, O nauce, rozumowaniu $i$ wartościach. Pisma wybrane, Wyd. Naukowe PWN, Warszawa.

50. UN, 2015, Transforming our World: the 2030 Agenda for Sustainable Development, Resolution adopted by the UN General Assembly on 25 September 2015.

51. WIENER N., 1961, Cybernetyka a społeczeństwo, Wyd. Książka i Wiedza, Warszawa.

52. WALKER P., 2006, Change Management for Sustainable Development, IEMA Best Practice Series, Vol. 7.

53. VAN DER VORST R., 1998, Engineering, Ethics and Professionalism, in: European Journal of Engineering Education, Vol. 23, No. 2, p. 171-179.

54. ZIĘBA S., 2013, Życie. Koncepcja emergentystyczna, Wyd. Naukowe PWN, Warszawa. 
